Meta

Journal des traducteurs

Translators' Journal

\title{
Audesc: Translating Images into Words for Spanish Visually Impaired People
}

\section{Ana I. Hernández-Bartolomé et Gustavo Mendiluce-Cabrera}

Volume 49, numéro 2, juin 2004

URI : https://id.erudit.org/iderudit/009350ar

DOI : https://doi.org/10.7202/009350ar

Aller au sommaire du numéro

Éditeur(s)

Les Presses de l'Université de Montréal

ISSN

0026-0452 (imprimé)

1492-1421 (numérique)

Découvrir la revue

Citer cet article

Hernández-Bartolomé, A. I. \& Mendiluce-Cabrera, G. (2004). Audesc: Translating Images into Words for Spanish Visually Impaired People. Meta, 49(2), 264-277. https://doi.org/10.7202/009350ar
Résumé de l'article

Bien que la traduction audiovisuelle soit un domaine relativement récent dans les études de traduction, elle élargit ses perspectives à de nouveaux secteurs. Par exemple, des groupes minoritaires, comme les déficients sensoriels. Concrètement, les non-voyants et les amblyopes forment un groupe encore non étudié. Nous présentons le système de l'audiodescription, qui traduit les images en mots pour rendre les produits audiovisuels accessibles aux secteurs sociaux ayant des besoins spécifiques. Étant donné qu'il n’y a pas beaucoup de littérature disponible, nous fournirons les précédents et quelques procédés généraux pour ce genre de traduction intersémiotique. Cependant, nous nous intéresserons principalement à Audesc, le project audiodescriptif espagnol développé par la ONCE (l'Organisation nationale espagnole des Aveugles), appliqué spécialement au cinéma et au théâtre. Pour terminer, notre article abordera la fusion des rôles de l'audiodescripteur et du traducteur audiovisuel. 


\title{
Audesc: Translating Images into Words for Spanish Visually Impaired People
}

\author{
ANA I. HERNÁNDEZ-BARTOLOMÉ \\ Universidad de Valladolid, Valladolid, Spain \\ aihb@fyl.uva.es \\ GUSTAVO MENDILUCE-CABRERA ${ }^{1}$ \\ Universidad de Valladolid, Valladolid, Spain \\ gustavom@itbyte.uva.es
}

\begin{abstract}
RÉSUMÉ
Bien que la traduction audiovisuelle soit un domaine relativement récent dans les études de traduction, elle élargit ses perspectives à de nouveaux secteurs. Par exemple, des groupes minoritaires, comme les déficients sensoriels. Concrètement, les non-voyants et les amblyopes forment un groupe encore non étudié. Nous présentons le système de l'audiodescription, qui traduit les images en mots pour rendre les produits audiovisuels accessibles aux secteurs sociaux ayant des besoins spécifiques. Étant donné qu'il n'y a pas beaucoup de littérature disponible, nous fournirons les précédents et quelques procédés généraux pour ce genre de traduction intersémiotique. Cependant, nous nous intéresserons principalement à Audesc, le project audiodescriptif espagnol développé par la ONCE (l'Organisation nationale espagnole des Aveugles), appliqué spécialement au cinéma et au théâtre. Pour terminer, notre article abordera la fusion des rôles de l'audiodescripteur et du traducteur audiovisuel.
\end{abstract}

\begin{abstract}
Although audiovisual translation is a relatively new field within Translation Studies, it is widening its perspectives to recent areas. Some of them are particularly concerned with minority groups, such as sensory impaired people. Specifically, the blind and visually impaired constitute an unexplored group. In this paper we introduce the system of "audio description," which translates images into words to make audiovisual products accessible to this special-needs social sector. Since not much literature on the topic is available, we will provide the background and some general procedures for this type of intersemiotic translation. However, our greatest interest will be Audesc, the Spanish audio descriptive project developed by ONCE (the Spanish Organisation for the Blind), mainly applied to the cinema and the theatre. Finally, our paper hints at attaching the audio describer's role to the audiovisual translator's.
\end{abstract}

\section{MOTS-CLÉS/KEYWORDS}

audiovisual translation, intersemiotic translation, audio description, blind and visually impaired people, Audesc.

\section{Audiovisual translation within Translation Studies}

Translation Studies (TS) cover a vast area which has been constantly growing. Since TS were considered an academic discipline in its own right thanks to the well-known contributions of Vinay \& Darbelnet in the late fifties and Holmes in the early seventies, literary translation was no longer the only field of preoccupation for scholars. 
New linguistic approaches such as corpus linguistics (Baker 1995) and contrastive rhetoric (Fernández Polo, 2002) appeared, gained importance and eventually became recognised as independent disciplines and have contributed to the expansion of the scope of TS. As a result of this multidisciplinarity, TS have widened and narrowed at the same time, so many new sub-areas (scientific, legal, business or audiovisual translation, dialogue interpretation...) were born within the major area of TS.

But most importantly, these new subareas have become or are becoming professionalised. This means that their social implications are paramount, both in quantitative terms of job creation and in qualitative terms of social services. Let us take a case in point: through the 1990's, American films represented about $80 \%$ of box office receipts in Europe (El País, 23 May 2001, p. 43, cited in Bravo Gozalo, 2002: 189). Taking into account that in many European countries American films have to be dubbed - as in France or Spain - or subtitled - as in Belgium and Portugal - in their respective official languages, this type of translation becomes preeminent for a great part of the European entertainment industry. Thus, it is easy to imagine how important screen translation can be, and partly why this paper focuses on audiovisual translation (AVT). ${ }^{2}$

Before stating the outline of this paper, there are a few related terms that need to be clarified in order to fully understand the concept of AVT as a special type of translation: constrained translation, multimedia translation, and film translation. AVT is included within what some scholars call "multimedia translation" (Agost, Chaume \& Hurtado, 1999: 182). This concept covers translations wherein: a) information is provided through at least two channels, and b) new technologies are involved. Together with AVT, software localisation is another example of multimedia translation with its own specifics (Mendiluce-Cabrera \& Bermúdez-Bausela, in press). Conversely, "film translation" is one type of AVT, perhaps the best known. Finally, from bottom to top, film translation, AVT and multimedia translation are all included within the general category of "constrained translation." Initially, it was Titford (1982) who applied this term to subtitling, but Mayoral, Kelly \& Gallardo (1988) later expanded the meaning of constrained translation to include, among others, the translation of comics, songs, advertising, and any type of AVT. Since then, constrained translation is usually understood in that broader sense (Rabadán Álvarez, 1991: 149).

\section{Audio description within audiovisual translation}

AVT studies are flourishing nowadays, the first such milestone having been established in 1960. However, it was not until the 80's and especially the 90's that AVT gained importance. This boom can be observed in the increasing volume of research through the last decade (Bravo Gozalo, 2003: 236; Chaume Varela, 2002: 215). Interestingly, most of the work in this field has focused on the description of the translation process, while some other areas of AVT remain unexplored. One of them is translation for the disabled, such as deaf, hard-of-hearing, blind and visually impaired people. Scholars agree that these special kinds of translation are most likely to be fruitful in the near future, a fact that may be attributed to social integration policies (Bravo Gozalo, 2003: 247; Chaume Varela, 2002: 217). While there is at least one seminal study on translation for people with hearing disabilities (Linde \& Kay, 1999) and some papers have devoted a specific, if brief, section to this social sector (Mayoral Asensio, 
2001: 38), we know of no equivalent academic publication about translation for visually impaired people, which is called audio description (henceforth, AD). Figure 1 illustrates how AD fit into TS and the concepts previously discussed.

Notwithstanding this lack of background, $\mathrm{AD}$ can be analysed from a wide range of perspectives. For our purposes, intersemiotic translation is the cornerstone. According to Jakobson (1971: 260,330), it consists in the transfer from a particular semiotic code to a different code; in this case, iconic information must be turned into verbal information, images into words. Hence, the two main semiotic codes of AVT are present in the intersemiotic transfer of $\mathrm{AD}$.

Considering that research gap in a potentially highly productive field, this paper attempts to present the state of the art in $\mathrm{AD}$ for the blind and visually impaired. More particularly, our approach will pay special attention to the Spanish experience; still, whenever necessary (e.g. to provide background or offer a contrast), references to other countries will be made.

\section{Audio description: aims and definition}

As may seem obvious, the iconic essence of the audiovisual products is the source of isolation for blind and visually impaired people. This does not mean they do not like cinema, theatre, television, etc.; it only implies they have objective difficulties in gaining access to this artistic and particularly restricted entertainment. The sounds and dialogues they can perceive are not enough to fully enjoy a film or play; they need additional help to associate the images attached to them. And this is precisely the field of action of AD: it aims to build a bridge in order to bring audiovisual products closer to visually impaired people. This minority group is not statistically insignificant. Although quantification of blind people is quite controversial, in 1994 the WHO estimated that the number of seriously visually impaired people in the world totalled 148 million. Nowadays, in Spain there are approximately 63,000 blind or low-vision people (Villaécija, 2002).

In translating images into words, $\mathrm{AD}$ pursues two different goals: integrating and cultural. With the first objective, $\mathrm{AD}$ helps this minority group to feel part of the society they are living in, since, for example, they can enjoy the same television programmes, go to the theatre with friends or take their children to the cinema. The system could also be delivered by radio or played on cassette, but they would not be able to enjoy the audiovisual product with their families. The second objective brings culture closer to blind people. Not only do they learn historic or literary details, but also - and more important - social ones. With the AD of habitual gestures - such as a finger on the lips - they can learn how to communicate and use them and, then, apply them to their lives (González \& Iorfida, 2002).

What exactly is this system? "AD is a commentary on scenery, costume, facial expression, body language and action inserted during the silent intervals of plays, films and television programmes to give information to blind and visually impaired people" (Silverwood, 1992: 10). It is an aural narration synchronised with the original sound track. AD should try to describe meaningful details and evade obvious or wellknown details. "There are three golden rules to description: describe what is there, do not give a personal version of what is there and never talk over dialogue or commentary" (ITC, 2000: 8). Sceneries, costumes, facial expressions, etc. should be described 
when relevant, and arranged throughout the audiovisual product - for example, an average film may have from 400 to 500 audio described fragments (Navarrete Moreno, 1997b: 74). There are many approaches to AD, not only because describers' styles differ, but also because the audience is varied in needs, expectations and experiences (ITC, 2000: 3). Furthermore, for the time being, there are not universal guidelines for AD (Clark, 2001).

$\mathrm{AD}$ services can be provided for television programmes (pre-produced and some live programmes, also for digital television), feature films, DVDs, home videos, and websites in streaming-media environments. But there are an enormous number of other events that can also be described, such as theatre, opera, dance, museum exhibitions, meetings, tours, circuses, parades, and sports events. Therefore, AD is presumed to signify a cultural revolution for blind and visually impaired filmgoers.

\section{The development of audio description}

As may seem evident, $\mathrm{AD}$ is as old as sighted people telling blind people about the images surrounding them. However, from a technical point of view, the phenomenon is much more recent. The degree of development varies from country to country, with the major focus being America and Europe. For our purpose we will pay special attention to Spain, which is the home country of Audesc.

AD got its start in the United States in 1981?more precisely, at the Arena Stage in Washington DC? due to the Pfanstiehl family. This date was crucial, as it coincides with the foundation of the AD Service, which rapidly promoted this system over 50 theatres by the end of the 1980's (ITC, 2000: 3). Various projects opened new perspectives, such as the Audio Vision project developed at San Francisco State University (Silverwood, 1992: 12). With respect to home development, in 1990 the MoPix project created the Descriptive Video Service, with AD videotapes. Later, it developed into a more suitable format which does not alter the sighted reception of the product (NCAM, 2003). Then, the US became the nest of broadcast transmission with this system, which now reaches half of US homes through the additional audio channel on American cable television (ITC, 2000: 4).

The mid-1980's marked the first performances in Europe, with the starting point considered to be the Robin Hood Theatre at Averham (United Kingdom). One of its playwrights then encouraged the Theatre Royal in Windsor to develop this system. Today has Europe more than 40 theatres equipped with AD, with the United Kingdom and France being the leaders in performances. Cinema has also served as a means for bringing the Arts to visually impaired audiences: the British Chapter Arts Centre in Cardiff was the first to describe using live script readers, followed by the French Association Valentin Haüy and its portable service (ITC, 2000: 3). Last, but not least, television has played a main role in the development of AD. The mid-1990's included a milestone in legislation with the 1996 Broadcasting Act (ITC, 2000: 2).

The 1990's have been the most productive era for European AD. There have been three main projects: Audetel in the United Kingdom, Audiovision in France and Audesc in Spain (Navarrete Moreno, 1997b: 70). In 1991 the Audetel consortium was founded by the ITC, the BBC, the RNIB, and the financial support of the European Commission, beginning a regular described service in Europe. It also took into account the videotape field, Hear My Song being the first film to be audio described (González 
\& Iorfida, 2002). The Audiovision project, began in 1989 and changed to ARTE in 1998, providing both description in television broadcasting and live description in theatres (ARTE, 2003).

Spain has also played an important role in $\mathrm{AD}$. The dramatised narration of plays on radio has been a traditional entertainment for decades in Spain, both for sighted and visually impaired moviegoers. However, the real beginning of AD has taken place in the last two decades. As the situation in Europe and the US was improving for the blind audience, the Spanish community started to get involved in the advantages they could enjoy. In 1985 a blind doctor, Miguel Hidalgo, suggested to ONCE, the Spanish National Organisation for the Blind, a way to bring the visual arts to its members. As a result, a new audio descriptive method, Sonocine, appeared in 1987. Its aim was to adapt videotapes with $\mathrm{AD}$, contrary to the American method which worked directly on the original celluloid. The system proved very sucessful and the organisation tried to widen its horizons (Cejudo, 1991: 28). As a consequence, Spain was the first western country to adapt television for disabled moviegoers - just after the occasional description of the Japanese network NTV from 1983 - when the Catalonian channel broadcast some occasional open programmes in the late 1980's using one of the stereo audio channels. However, these broadcasts were added to the usual programme sound and could be heard by the whole audience, which proved unsuitable for the sighted spectators (ITC, 2000: 4).

With the passing of time, Sonocine changed its objectives from a home audience to an integrating one, including $\mathrm{AD}$ for commercial representations, life performances and regular television programmes. That was the origin of a new system in 1994: Audesc (García Mateache, 2003: 13).

Clearly enough, $\mathrm{AD}$ has undergone an increasing process in the last two decades. As a result, some general rules have been established as the principles to this process. Some of them are (ITC, 2000: 11-22; Clark, 2001):

- The use of the present tense for the narration, which derives from the fact that the audience needs to be told what is happening at a particular point in time.

- The adequate treatment of the information. Clarity is the objective and anything unessential must be weeded out to prevent diluting the mood of the audiovisual product. Information should be given as the action is taking place; whenever impossible, it is usually narrated a few seconds before the action. In some cases additional information may be added to accomplish the cultural nature of AD. However, overinterpretation should be avoided, as well as censorship with sexual or violent language.

- Proper names are repeated to make the spectator become familiar with the characters. Consequently, pronouns should be avoided when ambiguous.

- Wide use of vocabulary. Descriptive verbs, adjectives and adverbs are a useful hint to stimulate the receptors' imagination. Colours and ethnic traces should be described when relevant to keep the connotations they may bear. Despite the rich vocabulary, we should always be accessible to the public and coherent throughout the description.

- Titles, credits and the AD information are also recorded, as it is part of the copyright duties.

The coherence of these clues is bound to impact directly on the reception of AD and, consequently, on the effectiveness of the system. 


\section{Audesc: the Spanish experience}

Despite the fact that it has been running for a decade, there is hardly any information about Audesc. In a recent publication, Bravo Gozalo (2003: 246-247) makes a general reference to the purpose, origin and application of this system, but he does not provide further details about these aspects, and about how it works or how successful it is. To our knowledge, only two papers give a thorough description of Audesc and both can be found in a non-academic journal published by ONCE (Navarrete Moreno, 1997a \& 1997b).

Basically, Audesc was based on the previous project, Sonocine, but with more ambitious perspectives. Its main drawback is obtaining the producers and distributors' authorisation: the propriety rights waived by the SGAE (Spanish Authors Society) and the dispersion of the market have slowed down the AD rhythm (Cejudo, 1991: 28).

However the difficulties, ONCE has fought over the last decade to bring all sorts of culture closer to its members, the result appearing in 1994 for the first time. The first audio described products with Audesc were Basic Instinct, Belle Époque, Casablanca, High Heels and Home Alone (Galisteo, 1994: 5). This proves that embracing any time, genre and style of audiovisual products are key objectives of AD. For this reason, the first products included family audiences, classical styles, blockbusters, action and adult films. The result of different surveys appeared in November 1996, when ONCE created a catalogue - provided with a search tool - with all the videotapes for the members of the organisation (Navarrete Moreno, 1997b: 74).

Today, only a decade after its origins, Audesc has changed the life of the blind and visually impaired groups. Some recent achievements have covered the different fields of action, acknowledged with the Tiflos Award for novels, documentaries, radio programmes, poems, etc, whose first contest for shorts took place in 2003. With respect to television broadcasting, the national network TVE1 for a long time provided regular $\mathrm{AD}$ for a cartoon series (Nicolás), and a regional channel (Canal Sur) synchronises its television and radio networks to provide some films with Audesc. In the cinema field, in 2002 some well-known festivals are adapting this system, such as the 47th Valladolid International Film Festival, which started AD with the film Don Quixote, Knight Errant; and the 28th Iberoamerican Film Festival of Huelva, which described the films Poniente and The Suit. With respect to the theatre, plays are regularly described in Madrid, and some companies have adopted this method in other big cities. Finally, videotape coverage has been increasing in recent years, both in number of products - currently, 234 tapes - and in number of spectators, figures which have highly surpassed other visually impaired systems. ONCE also provides alternative movie resources: a codified radio channel in which films are described on a weekly basis, a video-forum to discuss the social and cultural aspects of a particular movie, film projections for elderly people, etc. Audesc has made remarkable advances in the integration of blind and visually impaired people, but there is still much work to be done in the coming years.

\section{Audesc in the cinema}

Despite the highly visual component of cinema, its essence is conveyed by two elements: the dramatic, where the action or story is narrated, and the plastic, which is represented in the moving images. Therefore, Audesc will be applied to the dramatic component. 
Its development still needs to promote collective performances, that is to say, to develop the system in commercial movie theatres. We will first describe the process to further give exclusive details of the cinema.

The average time of the complete process of $\mathrm{AD}$ for a two-hour film is estimated to take one describer about 60 hours, that is to say, a working week and a half. These hours should be devoted to the following steps (ITC, 2000: 7-11; Navarrete Moreno, 1997b: 71-4):

1. Choosing suitable films. At the beginning of every year, ONCE holds a meeting where a list of films is prepared, intending to cover the variety of genres, styles and times. Different groups are asked to give their opinion: members, film experts, and ONCE Committee of Culture. The policy of the organisation is to meet the demand without giving in to consumerism. However, some films are not suitable for description. If there is more action than dialogue, the description would be almost continuous and the result could be tiring to listen to, even irritating. Furthermore, the excess of $\mathrm{AD}$ can dilute the mood of an overall scene. $\mathrm{AD}$ becomes a hindrance rather than a help in cases where the gap between the narration and the original dialogue are too brief.

2. Viewing the film. The descriptor should pay attention to the style, plot, scenery, environment, etc. And be faithful to the film mood. Audesc tries to avoid films with sound problems, as some of the members could suffer presbycusis. In some cases, films are digitally remastered to improve the sound quality. A useful hint for describers is to "view" the film without the pictures or use simspecs (a pair of glasses that simulate visual impairments).

3. Preparing a draft script. The script should describe the meaningful images and avoid the obvious ones, as we have already said. First of all, the documentation of the script will be vital, as the description aims at providing cultural interests. For this reason, terminology should be precise and any detail should be carefully described (if decisive for the action).

4. Synchronising the description. Explanations would ideally be heard while the action is taking place. This utopia is seldom achieved and experience suggests that descriptions tend to appear just two seconds before the images. Thrillers should receive special treatment, since the description could be delayed after the action in order not to anticipate events and destroy the film's atmosphere.

5. Rehearsing the description. The narration should express the feelings of the film as if being experienced by a sighted filmgoer. "Good AD should be unobtrusive and neutral, but not lifeless or monotonous and the delivery should be in keeping with the nature of the programme" (ITC, 2000: 9). Therefore, the narrator should perform the description dramatically. Dubbing actors are particularly suitable for this purpose, as they are used to work with takes and their voices comfortably fit in the film. Their voice should never be confused with one of the characters in order to avoid misunderstandings, but at the same time, should be integrated within the film as a whole. Surveys indicate that either a male or a female voice is acceptable; in fact, both are frequently used together - one for the action and the other for the titles and written content.

6. Reviewing the description. Senior describers could improve the quality of the description and teach new techniques. Script approval from film producers may be 
rarely needed. It is important here to rehearse the description many times, acting as if live.

7. Recording the description. It should be carefully supervised because of its complexity. Original sound tracks are examined and, when necessary, improved in quality; voices are equalised to the general sound level of the film; the frames of the description are synchronised and adjusted; and each and every sound is levelled to arrange the fades. This is the toughest part of the work because describers exhaustively examine the process to reach high-quality standards. The average recording time for a one-hour description is estimated to take approximately from two to two and a half hours.

8. Reviewing the recording. Final mistakes and omissions should be corrected to avoid an imperfect performance or delivery.

9. Distributing the audio described film. Films finally have to be delivered to every local office. ONCE distributes the same videotapes to all the Spanish territory. Some libraries will have various copies of the tapes, but others will not have the complete list, the availability depending on the number of members in the area. Every regional section will be provided with various copies of the films, and the regional head office will be in charge of the distribution. With respect to the product, each film will be provided with a case with the title in Braille, the essential data of the film and a brief summary of the plot. ONCE members enjoy these films for free and the service is highly requested.

The same system is currently being applied to DVD format. Nonetheless, there are some incompatibilities between DVD copies and players, so the process is slower than expected. Actually, there are only 12 films AD in DVD, but ONCE technicians expect to overcome the problem before long (García Mateache, 2003: 13).

Although the $\mathrm{AD}$ process is the same, commercial cinemas have a special kit for blind and visually impaired filmgoers. Any disabled person in the session is provided with a single headphone. Thus, while one ear listens to the narration, the other one is kept open for the original sound of the film. This receptor is transmitted the synchronised version with the motion picture. There is no need for the audio describer to be present in the session, for the $\mathrm{AD}$ is already fully prepared and the only thing to do is play the recording at the exact moment. Cinema AD is not widely spread in the Spanish territory, 2002 being the first year to be adopted. It seems that its use is increasing quickly, but, as far as we are concerned, there is no cinema with regular $\mathrm{AD}$ yet. Festivals have been quickly integrating this system to their contests in the last two years, but social awareness still needs to be encouraged. The commercial market looks poised to expand in the coming years with very high acceptance of home described films. At the end of 2003, the Audesc catalogue included 14 documentaries and 220 films. As regards the year of production of each film, table 1 shows there was a similar tendency from the 1950's to the 1980's; the 1990's, though, seem to double the number of tapes. This increase appears to be continuing in the 2000 's although it is a bit early to predict the final results. ${ }^{3}$ 


\section{Audesc in the theatre}

Audesc has also been applied to theatre. In this case, the process, albeit based on the previously described AD for films, differs substantially from it. Obviously, these divergences arise from the different nature of films and plays: first, plays are live while films are recorded; secondly, theatre depends on speech much more than on images, as opposed to cinema. Thus, narration is different both in quantitative - less information is required and there are also fewer sound gaps - and qualitative terms - the speech rhythm varies in each performance. Because of the latter factor, Audesc has been applied to Spanish amateur and professional theatre with different results. Plays performed by professional actors seem to be much better audio described, as sudden changes are less likely to occur, so there is no need for the speaker to improvise. This explanation can account for the fact that in October 2001 (INAEM, 2003) ONCE and INAEM (the Spanish Institute for the Stage Arts and Music) signed an agreement whereby permanent equipment was installed in three important Madrid theatres (Teatro de la Comedia, María Guerrero, and La Zarzuela). Other communities like Andalusia, Basque Country, Catalonia, Galicia or Valencia have also enjoyed some sporadic performances.

With respect to the process, the script is also a key element. The theatre company should provide the audio describer with it about two weeks prior to the performance. Another basic element is getting a recording of a rehearsal to become familiar with the rhythm, costumes, scenography, etc. The describer might also attend a rehearsal to review and adjust the notes s/he had taken while watching the recording. A few minutes before the start of the performance, the narrator will read some information about the playwright, the play, the scenography, and the costumes. Once the play has begun, the narrator will inform the audience about the entrance and exit of characters, changes in the scenery, special effects, i.e. anything relevant that the visually impaired cannot perceive (Navarrete Moreno, 1997a: 28).

The technical details are very similar to those of film AD. The narrator works in a soundproof box, where s/he reads the script that the describer has previously and carefully written. As in the case of cinema, in order not to disturb the rest of the audience, the narrator's voice is transmitted to headphones through an infrared system.

\section{Other possible applications}

So far we have concentrated on Audesc as applied to cinema and theatre. This is due to the fact that up to now this system has been primarily applied to films and plays, while television, museums, conferences and other possible AV fields of application have remained in the background. Notwithstanding, we will briefly comment on them.

In countries like the US, England or France, some channels broadcast about ten hours of audio described programmes each week. In contrast, in Spain AD services for television are marginal. Curiously enough, a Catalonian channel is reported to have pioneered $\mathrm{AD}$ in the western world. Moreover, there are some interesting initiatives going on: a regional channel (Canal Sur) has been broadcasting films since 1995, and ONCE has been regularly providing a video loan service for its members since 1997. Interestingly, blind and low-vision people are happy with these initiatives but these services do not seem to be well-known among them. Perhaps a powerful 
public information campaign would be advisable to make television AD more popular in Spain. Apart from this reason, the limited success of $\mathrm{AD}$ in television remains a mystery to us. However, the future seems to be hopeful: tests are being conducted with the dual system; in addition, conversations are being held with digital TV platforms so that they will adapt technology to make it accessible to this special-needs social group (García Mateache, 2003: 13). Importantly, Mundovisión - a Spanish digital TV channel - has been broadcasting programmes for visually impaired people for some years.

Documentaries are indicated to apprise blind and visually impaired people of a particular subject matter. Nature documentaries are especially appreciated as they describe what the world looks like. Because of that, this material is difficult to produce. The same is true of news and sport programmes, for instance; in this case, the reasons are quite different: there are hardly any sound gaps between images.

As regards museums, the situation is not much better. Government support is not as forthcoming as may be expected, so improvements are slower than desirable. Despite these difficulties, some museums provide special services on an individual basis, although specific AD services are rarely available. The same may be applicable to the theme parks and national parks.

Finally, conferences, symposiums and courses should have a permanent service that is not available for the moment in Spain.

\section{Final reflections}

We do not think this paper would be complete without a discussion of the importance of $\mathrm{AD}$ as a new specialised type of translation. In particular we wish to emphasize two different repercussions: society and the labour market.

Let us begin with the social repercussions. The importance of $\mathrm{AD}$, subtitling for the deaf, as any other example of new technologies for disabled people undoubtedly derives from an increasing awareness of the necessary insertion of this social group. It is only thanks to technology that these new systems are developed, but it is only thanks to social awareness that technology is used for developing them. It would be advisable that governments all over the world take the necessary steps to favour this social integration. Some excellent and hopeful signs of this useful common policy were the 1996 Broadcasting Act, the Regulations 2003 of the Disability Discrimination Act 1995 (Amendment) Regulations 2003 and, more recently, the designation of 2003 as the European Year of People with Disabilities (EYPD, 2003). Another important and recent milestone in AD was December 3, 2003, the International Day of Disabled Persons. To celebrate it, Channel Five became the first UK public service broadcaster to launch $\mathrm{AD}$ services on digital satellite television. As a result, more than seven million homes in the UK and Ireland can now enjoy those services (SKY, 2003).

As regards Audesc receptivity, two different surveys carried out by ONCE in Spain have shown that this minority group has been very happy with the work done on $\mathrm{AD}$ since the beginning. The first survey was just a pilot study to sound out the reaction of 300 people; later, a more efficient follow-up survey was designed: during 1995 any member of ONCE borrowing a described videotape was requested to fill out a questionnaire about their experience with video $\mathrm{AD}$. Most of them were happy with the variety of available films as well as with the narration, including the actors, 
scenery, costume, makeup and historical information (Navarrete Moreno, 1997b: 75). There are no significant differences with the American experience. (AFB, 1997). Interestingly, more than $20 \%$ of them believe that description may be distracting or annoying. That is one more reason for emphasising that $\mathrm{AD}$ must be done by a trained professional.

As a result of this social insertion, translators have a key role to play in this context, and the labour market has added two new types of professionals: describers and narrators. Focused on what is purely translation, describers are the most important ones. What are the specific requirements for a describer? In theory, what describers do is translate images into words, i.e. intersemiotic translation. Nevertheless, not anyone can do this job. Describers must be creative and socially sensitive and have a good command of new technologies. More specifically, Navarrete Moreno (1997b: 71) thinks that the persons responsible for this kind of translation must: a) be knowledgeable about cinema and/or theatre, both from the literary - styles, periods, and authors - and the technical point of view - about scenography, illumination, costume -, b) be learned and open-minded as regards cultural aspects, c) have good writing skills, and d) enjoy films and/or plays.

We observe a strong similarity between audio describers and specialised translators: the latter must be very well informed about the field they are translating, about the concepts and their corresponding terms; simlarly, the former must be knowledgeable about film and/or theatre techniques and language. In the same way that specialised translators must know their target audience - the needs and preferences of the clients - describers also have to know their audience - the needs and preferences of blind and visually impaired people. Consequently, we see the describer as a new type of specialised translator, and feel that describers should also be professional audiovisual translators and, ideally, the same translators of the product in question. Apart from being technically and linguistically qualified to do the job, they are the most familiar with the product.

There are no major economic obstacles to $\mathrm{AD}$. Adapting a movie theatre costs around 6,000 euros, and the distributor would have to pay approximately the same amount for audio describing a film. In practice, these figures imply that such an investment would achieve a return in 40 sessions assuming 20 blind people were to attend them, according to the estimates of Ignacio Escanero, ONCE Director of Cultural Activities (Villaécija, 2002). However, time may be the main drawback of this type of translation, both in cinema and theatre. This further supports our suggestion that $\mathrm{AD}$ should be done by professional translators. They are the ones who best know the film or the audiovisual products in question. They had to watch it, read it, study it, so they have become familiar with it. They already know the background and the terminology. Let us remember that about $80 \%$ of films watched in a great part of Europe are translated. Consequently, much time would be saved. For all the reasons stated, audiovisual translators are the best candidates to be describers, from our point of view. Obviously, they should also be advised by a team of experts on what details are not necessary and how specific they must be. We think that AD would benefit greatly from this kind of co-operation, both in terms of time and quality.

$\mathrm{AD}$ might also be further improved if narrators could be selected according to the following functional criteria: dubbing actors would be perfect for describing films and interpreters would do their best in theatre AD. Both types of professional 
translators are used to perform similar jobs. Interpreters frequently improvise while conveying a message publicly (Agost Canós, 1999: 19-20), so they would not have a hard time when adapting the changing rhythm of the actors on stage. Theatre AD requires the same equipment as simultaneous interpretation (Navarrete Moreno, 1997a: 28), and dubbing actors know how to work with recorded images and takes.

In conclusion, $\mathrm{AD}$ is a nascent form of AVT that is very likely to become very important in the near future. Moreover, because of its special knowledge and training requirements as well as its special-needs audience, AD is a new type of specialised translation. Therefore, as an audiovisual and specialised type of translation, AD may reach the best quality standards if it is done by highly qualified professional audiovisual translators.

\section{ACKNOWLEDGMENTS}

Thanks are due to Chantal Hubert for her help with the French version of the abstract. We also want to express our gratitude to Javier Andaluz, Rubén Arenas and Jesús Rodríguez, for kindly introducing us to Audesc and providing us with real data.

\section{NOTES}

1. Holders of a research grant from the Spanish Ministry of Education, Culture and Sports.

2. In this paper, we use the terms screen translation and audiovisual translation as synonyms. Although the former seems to be more commonly used nowadays (O'Connell, 2003: 222), we prefer the traditional one.

3. Due to the controversial nature of film genres, we did not dare include a final classification. However, according to our tentative research results, drama, romantic comedy and family cinema are the leading film categories. Nonetheless, the integrating aim of Audesc covers all possible genres, from horror to science-fiction, musical or western films.

\section{REFERENCES}

Agost Canós, R., F. Chaume Varela and A. Hurtado Albir (1999): "La traducción audiovisual." In Hurtado Albir, A. (ed.): Enseñar a traducir: metodología en la formación de traductores e intérpretes, Madrid, Edelsa, pp. 182-195.

AFB (American Foundation for the Blind) (1997): "Who's watching? A profile of the blind and visually impaired audience for television and video," <http://www.afb.org/info_document_ view.asp?documentid $=1232 \# t 4>$.

ARTE (2003): "L'audiovision pour aveugles et mal-voyants," <http://www.arte-tv.com/arteinfo/ ftext/ empfang/audio.htm>.

BAKer, M. (1995): "Corpora in translation studies: an overview and some suggestions for future research,” Target, 7-2, pp. 223-243.

Bravo Gozalo, J. M. (2002): “Translating the film dialect of Hollywood for dubbing." In Bravo Gozalo, J. M. (ed.): Nuevas perspectivas de los estudios de traducción, Valladolid, Universidad de Valladolid, pp. 187-213.

Bravo Gozalo, J. M. (2003): “La investigación en traducción audiovisual en España." In García Peinado, M. A. \& E. Ortega Arjonilla (dirs.): Panorama actual de la investigación e interpretación (vol. 2), Granada, Editorial Atrio, pp. 235-252.

Cejudo, M. (1991): "Museo tiflológico y sonocine, dos proyectos de la O.N.C.E," Integración 5, pp. 26-28.

Chaume Varela, F. (2002): "Nuevas líneas de investigación en la traducción audiovisual." In Bravo Gozalo, J. M. (ed.): Nuevas perspectivas de los estudios de traducción, Valladolid, Universidad de Valladolid, pp. 215-224. 
Clark, J. (2001): "Standard techniques in audio description," <http://joeclark.org/access/ description/ad-principles.html>.

Clark, J. (2001): "Comments on U.K. guidelines on audio description," <http://joeclark.org/ access/description/ukad.html>.

Galisteo, J. R. (1994): “Cine para ciegos,” El Mundo, Comunicación, 6-211, p. 5.

EYPD (European Year of People with Disabilities) (2003): <http://www.eypd2003.org/eypd/ index.jsp $>$.

Fernández Polo, F. J. (2002): “Relevancia de la retórica contrastiva para la traducción.” In Bravo Gozalo, J. M. (ed.): Nuevas perspectivas de los estudios de traducción, Valladolid, Universidad de Valladolid, pp. 57-80.

García Mateache, J. M. (2003): “¿Vemos una 'peli’ el sábado por la noche?” Así somos, 9, pp. 1213.

GonZÁLez, L., E. IoRfida (2002): Cine a ciegas, <http://www.cineaciegas.galeon.com/index.html>.

Hernández Bartolomé, A. I. (2003): La traducción del humor en el cine: aspectos lingüísticos y culturales en Duck Soup de los Hermanos Marx, PhD dissertation, Universidad de Valladolid.

INAEM (Instituto Nacional de las Artes Escénicas y de la Música) (2001): <http://wwwinaem. mcu.es/ractual.htm>

ITC Guidelines on Standards for Audio Description (2000): <http://www.itc.org.uk/itc_publications/ codes_guidance/audio_description/index.asp $>$.

Jakobson, R. (1971): Selected Writings II. Word and Language, The Hague/Paris, Mouton.

Linde, Z. DE; N. KaY (1999): The Semiotics of Subtitling, Manchester, St. Jerome.

Mayoral Asensio, R. (2001): “Campos de estudio y trabajo en traducción audiovisual." In Duro, M. (coord.): La traducción para el doblaje y la subtitulación, Madrid, Cátedra, pp. 19-45.

Mayoral Asensio, R., D. Kelly and N. Gallardo (1988): "Concept of constrained translation: non-linguistic perspectives of translation," Meta, 33-3, pp. 356-367.

Mendiluce Cabrera, G. and M. Bermúdez Bausela [in press]: "Sci-tech translation: is there an internationalization process in English and Spanish?," Meta.

Navarrete Moreno, F. J. (1997a): “Aplicación al teatro del sistema AUDESC," Integración, 24, pp. 26-29.

Navarrete Moreno, F. J. (1997b): “Sistema AUDESC: el arte de hablar en imágenes,” Integración, 23, pp. 70-75.

NCAM (National Center for Accessible Media) (2003): "Motion Picture Access," <http://ncam. wgbh.org/mopix/aboutproject.html>.

O'Connell, E. (2003): "What dubbers of children's television programmes can learn from translators of children's books?," Meta, 48-1\&2, pp. 222-232.

RabadÁn Álvarez, R. (1991): Equivalencia y traducción, León, Universidad de León.

RETEMIR (1999): II Feria del Teatro de Ciudad Rodrigo: "El fin de los susurros," <http:// www.ciudadrodrigo.net/feriateatro/feria99/ Audesc.htm>.

Silverwood, A. (1992): "Audiodescription," DAM (Disability Arts Magazine) 2-4, pp. 10-14, <www. leeds.ac.uk/disability-studies/archiveuk/disability\%20arts\%20mag/winter\%201992.pdf>.

SKY (2003): "Five to use BskyB's audio description technology," Disability Information, <http:// www1.sky.com/disability/release2.htm>.

Titford, C. (1982): “Subtitling - constrained translation," Lebende Sprachen, 27-3, pp. 113-116.

VIllaÁ́ciJA, I. (2002): "Éxito tras la proyección de la primera película en sistema Audesc" (interview to Ignacio Escanero, ONCE Director of Cultural Activities), <http://www.festicinehuelva. com/28edicion/0114112002.html>. 


\section{APPENDIX}

FIGURE 1

\section{Audio description within Translation Studies}

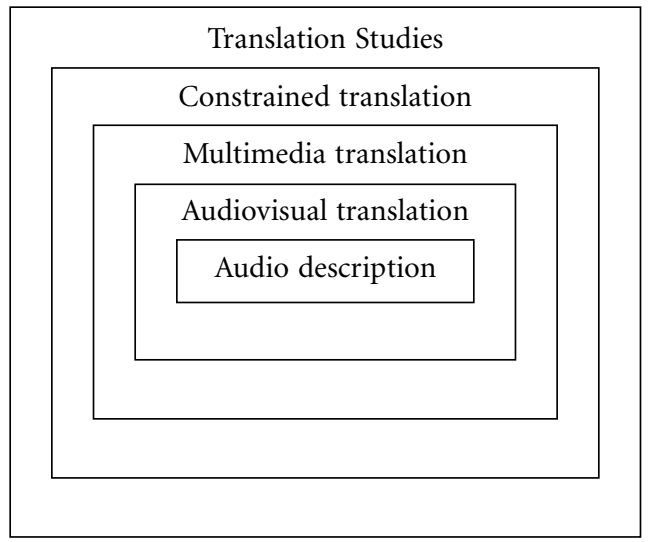

TABLE 1

Distribution of Audesc films according to their date of release

\begin{tabular}{|l|c|}
\hline Years & No. of films \\
\hline 2000 's & 24 \\
\hline 1990 's & 70 \\
\hline 1980 's & 31 \\
\hline 1970 's & 21 \\
\hline 1960's & 25 \\
\hline 1950's & 30 \\
\hline 1940's & 9 \\
\hline 1930's & 8 \\
\hline 1920's & 2 \\
\hline TOTAL & 220 \\
\hline
\end{tabular}

